Institut za

javne financije
NEWSLETTER

POVREMENO GLASILO INSTITUTA ZA JAVNE FINANCIJE

\title{
Struktura trošarine na cigarete u Hrvatskoj
}

\author{
ANTO BAJO Institut za javne financije \\ MARKO PRIMORAC Ekonomski fakultet Zagreb
}

Europska unija je Republici Hrvatskoj do 20I7. odobrila prijelazno razdoblje za potpunu harmonizaciju trošarine na cigarete. Daljnjom harmonizacijom treba očekivati rast trošarine i cijena cigareta. ${ }^{I}$ Osim visine, Hrvatska treba pozornost usmjeriti i na strukturu trošarine koja u značajnoj mjeri može utjecati na veličinu proračunskih prihoda. Zakonskim izmjenama strukture trošarine treba prethoditi cjelovita analiza njenih fiskalnih i gospodarskih učinaka.

\section{UvOD}

Proizvodnja duhana u EU-u čini 4,I\% svjetske proizvodnje, a ukupna prodaja cigareta u EU-u smanjuje se sa 793,7 mlrd. komada u 2000. na 608,8 mlrd. u 20I0. Međutim, u istom razdoblju raste ilegalna trgovina s 56,6 na 80,5 mlrd. komada. Unatoč smanjenju obujma prodaje, ukupna tržišna vrijednost (mjerena $u$ tekućim cijenama) narasla je u tom razdoblju s 90,7 na 12I,3 mlrd. eura. Ukupna tržišna vrijednost cigareta čini $89 \%$ ukupne vrijednosti duhanskih prerađevina, čija je vrijednost 20Io. iznosila I36,5 mlrd. eura (Matrix insight, 2012).

Sustav oporezivanja cigareta te visina i struktura trošarine značajno utječe na potrošnju. Trošarina se uvodi zbog prikupljanja prihoda, ispravljanja negativnih vanjskih učinaka (štetno djelovanje na zdravlje utječe na rast troškova zdravstva) i smanjivanja potrošnje. Pored izraženih društvenih, trošarina na cigarete ima i značajan fiskalni učinak jer povećava proračunske prihode. U svrhu harmoniziranja poreznih sustava zemalja članica, EU je donio nekoliko smjernica o trošarinama. Hrvatska je obvezna uskladiti zakonodavstvo s navedenim smjernicama, utvrđenom dinamikom postupnog prilagođavanja do 2017. što će utjecati na rast cijene cigareta, ali i proračunske prihode. Uz visinu, na prihode od trošarine uvelike utječe i struktura trošarine. Glavni je cilj rada utvrditi strukturu trošarine na cigarete u Hrvatskoj i u zemljama članicama EU-a i utjecaj promjene strukture trošarine na cijene cigareta. Dodatno se nastoji utvrditi razlike $u$ veličini i strukturi prihoda od trošarina na cigarete $u$ zemljama članicama EU-a i u Hrvatskoj.

\footnotetext{
${ }^{\mathrm{r}}$ Analize u Newsletteru ne obuhvaćaju promjene u visini trošarine nastale donošenjem Uredbe o visini trošarine na cigarete, sitno rezani duhan i ostali duhan za pušenje (NN 66/13.).
} 


\section{STRUKTURA TROŠARINA NA GIGARETE I HARMONIZACIJA U EUROPSKOJ UNIJI}

Trošarinu na cigarete čine dvije komponente: specifična i proporcionalna (ad valorem). Specifična komponenta trošarine utvrđuje se $\mathrm{u}$ fiksnom (apsolutnom) iznosu po komadu proizvoda (npr. trošarina na 1.00o komada cigareta), a proporcionalna u postotku maloprodajne cijene cigareta. ${ }^{2}$

Osim visine trošarine i osnovice, fiskalni učinak trošarine na cigarete znatno ovisi i o njihovoj strukturi. Struktura trošarine utječe na: cijene cigareta, ponašanje potrošača, proračunske prihode i duhansku industriju.

Iz različite strukture trošarine proizlaze i različite cijene cigareta među zemljama. To može utjecati na manje prihode proračuna zbog krijumčarenja ili legalne kupovine cigareta po nižim cijenama u susjednim državama. Potražnja za cigaretama je neelastična na promjenu cijena. Povećanje cijene neće značajno smanjiti ukupnu potražnju (malo potrošača prestaje konzumirati cigarete zbog promjene cijena), ali može utjecati na promjenu strukture potrošnje. Primjerice, povećanjem proporcionalnog dijela trošarine porasla bi apsolutna razlika u cijenama skupljih i jeftinijih cigareta, pa bi potrošači mogli supstituirati potrošnju skupljih jeftinijim cigaretama. Značajno povećanje poreznog opterećenja cigareta (ukoliko potrošačima prelazak na jeftinije supstitute ne bi bio prihvatljiv) može voditi ilegalnoj trgovini ili rastu legalne kupovine cigareta u pograničnim područjima sa zemljama s relativno nižim poreznim opterećenjem (npr. Srbija, Bosna i Hercegovina, Crna Gora).

\section{Tablica I.}

Osnovna obilježja specifične i proporcionalne trošarine na cigarete

\begin{tabular}{|c|c|c|}
\hline & Specifična & Proporcionalna \\
\hline \multirow{3}{*}{ 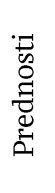 } & Predvidivi prihodi državnog proračuna & Automatska prilagodba za inflaciju \\
\hline & Smanjuje razliku u cijenama & Oporezuje se veća profitna marža \\
\hline & Lakša administracija i jednostavniji izračun & Štiti domaću proizvodnju \\
\hline \multirow{3}{*}{ 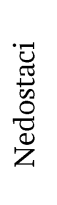 } & Inflacija smanjuje realnu vrijednost prihoda & Manje predvidivi prihodi \\
\hline & $\begin{array}{l}\text { Može rezultirati izmjenom karakteristika cigareta } \\
\text { s ciljem smanjenja ukupne osnovice }\end{array}$ & $\begin{array}{l}\text { Rastu razlike u cijenama, pa potrošači mogu } \\
\text { početi konzumirati jeftinije cigarete }\end{array}$ \\
\hline & Ne štiti domaću proizvodnju & Otežana administracija i izračun \\
\hline
\end{tabular}

Izvor: Prikaz autora na temelju (Ross, 2004:77; Keen I998: 5 i 6; Delipalla i O'Donnell, I998:IO; Cnossen, I992; 200I te Ross, 2004:77).

Trošarina na cigarete ima značajan fiskalni učinak koji ovisi o udjelima specifične i proporcionalne komponente. Osim izravnog utjecaja na porezne prihode, struktura trošarine može utjecati i na strukturu duhanske industrije. Povećanjem proporcionalne komponente raste razlika u cijeni jeftinijih i skupljih cigareta ( $u$ apsolutnom iznosu), pa potrošači mogu preferirati jeftinije cigarete. To može potaknuti proizvodnju jeftinijih cigareta. Povećanje specifične komponente smanjilo bi razliku u cijenama i motiviralo potrošače da konzumiraju skuplje (kvalitetnije) cigarete. Države koje imaju vlastitu proizvodnju i uzgoj duhana često preferiraju proporcionalnu trošarinu jer učinkom multiplikatora povećavaju cjenovnu prednost jeftinijih domaćih proizvoda u odnosu prema skupljim proizvodima multinacionalnih kompanija. Druge zemlje preferiraju specifičnu komponentu, jer proporcionalno oporezivanje povećava razliku u cijenama cigareta, pa potrošače potiče na konzumaciju jeftinijih cigareta što smanjuje porezne prihode.

\footnotetext{
${ }^{2}$ Maloprodajna cijena duhanskih prerađevina koje se puštaju u potrošnju na području Hrvatske je cijena koju za svaki pojedini proizvod utvrđuju proizvođači ili njihovi predstavnici ili ovlašteni posrednici u Hrvatskoj te uvoznici. Maloprodajna cijena uključuje trošarinu, carinu i porez na dodanu vrijednost (NN 22/I3., čl. 77, st. I).
} 


\section{TROŠARINA NA GIGARETE U HRVATSKOJ}

Trošarina na cigarete u Hrvatskoj regulirana je Zakonom o trošarinama (NN 22/13.), Pravilnikom o trošarinama (NN 64/13.) te Uredbom o visini trošarina na cigarete i sitno rezani duhan (NN 13I/I2.).

U Hrvatskoj se struktura trošarine na cigarete od 200o. mijenjala nekoliko puta uglavnom radi usklađivanja sa smjernicama EU-a (vidjeti tablicu 2). U početku su se cigarete oporezivale specifičnom trošarinom prema višetarifnom modelu (tri različite skupine cigareta: A, B i C). Višetarifni sustav ukinut je u lipnju 2009., kada je uvedena specifična trošarina od I80 kuna na I.ooo cigareta (za sve cigarete jednako) te proporcionalna trošarina u visini 30\% od maloprodajne cijene. Od tada je visina specifične trošarine ostala nepromijenjena. Međutim, proporcionalna trošarina porasla je na 33\% maloprodajne cijene u listopadu 20IO., a zatim na $36 \%$ u studenom 2012. Minimalna trošarina ${ }^{3}$ uvedena je 2010. u iznosu od 375 kuna na 1.00o cigareta, a krajem 2012. je povećana na 486 kuna na 1.ooo cigareta. Za potpunu harmonizaciju trošarine, EU je Hrvatskoj odobrio prijelazno razdoblje do kraja 2017. Daljnjom harmonizacijom očekuje se rast trošarine na cigarete.

\section{Tablica 2.}

Struktura trošarine na cigarete u Hrvatskoj

\begin{tabular}{|c|c|c|c|c|c|}
\hline Razdoblje & Osnovica & Minimalna & Skupina A & Skupina B & Skupina C \\
\hline \multirow{2}{*}{ I. $7.2000-15 \cdot 7.2004}$. & 20 kom. (kn) & & 5,0 & 5,4 & 8,9 \\
\hline & $\%$ MPC & & & & \\
\hline \multirow{2}{*}{ I5. 7. 2004-I. I. 2009.} & 20 kom. (kn) & & \multirow[t]{2}{*}{5,5} & 6,4 & IO,9 \\
\hline & $\% \mathrm{MPC}$ & & & & \\
\hline \multirow{2}{*}{ I. I. 2009-I. 6. 2009.} & I.ooo kom. (kn) & & $\mathrm{I} 75, \mathrm{O}$ & 197,5 & $3 \mathrm{IO}, \mathrm{O}$ \\
\hline & \% MPC & & \multicolumn{2}{|c|}{30} & \\
\hline \multirow{2}{*}{ I. 6. 2009-I. I. 2010.} & I.OOo kom. (kn) & & \multicolumn{2}{|c|}{180} & \\
\hline & $\% \mathrm{MPC}$ & & \multicolumn{2}{|c|}{30} & \\
\hline \multirow{2}{*}{ I. I. 2OIO-I. IO. 2010.} & I.ooo kom. (kn) & 375 & \multicolumn{2}{|c|}{180} & \\
\hline & $\% \mathrm{MPC}$ & & \multicolumn{2}{|c|}{30} & \\
\hline \multirow{2}{*}{ I. IO. 2OIO-29.II. $2 \mathrm{OI2}}$. & I.ooo kom. (kn) & 375 & \multicolumn{2}{|c|}{180} & \\
\hline & $\% \mathrm{MPC}$ & & \multicolumn{2}{|c|}{33} & \\
\hline \multirow{2}{*}{ 29. II. 2OI2-I. 7. 2013.} & I.ooo kom. (kn) & 486 & \multicolumn{2}{|c|}{180} & \\
\hline & $\%$ MPC & & \multicolumn{2}{|c|}{36} & \\
\hline \multirow{2}{*}{ I. 7. 2OI3-I. I. 2014.} & Minimalno $(\mathrm{kn}) \mathrm{r}$ & ooo komada & \multicolumn{2}{|c|}{486,4} & \\
\hline & Minimalni udio t & arine u PPMPC (\%) & \multicolumn{2}{|c|}{57} & \\
\hline \multirow{2}{*}{ I. I. 2OI4-I. I. 2018.} & Minimalno (kn) r & ooo komada & \multicolumn{2}{|c|}{585,2} & \\
\hline & Minimalni udio t & arine u PPMPC (\%) & \multicolumn{2}{|c|}{60} & \\
\hline \multirow{2}{*}{ I. I. 2018.} & Minimalno (kn) r & ooo komada & \multicolumn{2}{|c|}{684} & \\
\hline & Minimalni udio $t$ & arine u PPMPC (\%) & \multicolumn{2}{|c|}{60} & \\
\hline
\end{tabular}

Napomena: U izračunima minimalne trošarine propisane Direktivom (izražene u kunama), korišten je srednji devizni tečaj HNB-a za travanj 20I3. od 7,6 HRK za EUR.

MPC - maloprodajna cijena, PPMPC - prosječna ponderirana maloprodajna cijena cigareta puštenih u potrošnju.

Izvor: Zakon o posebnom porezu na duhanske proizvode (NN I36/O2., 95/O4., I52/o8. i 38/og.), Zakon o trošarinama (NN 83/o9., III/I2. i 22/I3.) te Uredba o visini trošarine na cigarete i sitno rezani duhan (NN I3I/I2.).

U prijelaznom razdoblju prilagodbe, od I. srpnja 2013. Hrvatska mora utvrditi minimalnu trošarinu u iznosu od 64 eura (486,4 kune) na I.ooo cigareta, pri čemu ukupna trošarina u prosječnoj ponderiranoj maloprodajnoj cijeni cigareta puštenih u potrošnju treba imati udio od najmanje 57\%. Od I. siječnja 2014. minimalna trošarina treba se povećati na 77 eura (585,2 kune) na I.ooo cigareta, a minimalan udio

3 Minimalna se trošarina plaća ukoliko je iznos ukupne trošarine na cigarete (specifične i proporcionalne), obračunat prema važećim propisima, niži od iznosa minimalne trošarine. 
trošarine u maloprodajnoj cijeni na 60\%. Do konačne (potpune) prilagodbe doći će 3I. prosinca 2017. kada će minimalni iznos trošarine rasti na 90 eura (684 kune) na I.ooo cigareta, bez obzira na prosječnu ponderiranu maloprodajnu cijenu cigareta puštenih u potrošnju (Marinović, 2013).

\section{PRIHODI I STRUKTURA TROŠARINE NA GIGARETE}

Trošarine su uz PDV najizdašniji porezni prihod državnog proračuna. Prihodi od trošarine na duhanske prerađevine u hrvatskoj rastu s 2,2 mlrd. u 2002. na 3,9 mlrd. kuna u 2012. te čine 2,7\% do 3,6\% ukupnih proračunskih prihoda (grafikon I).

\section{Grafikon I.}

Prihodi od trošarina na duhanske prerađevine od 2002. do 2012. (u mlrd. kuna i \% ukupnih prihoda)

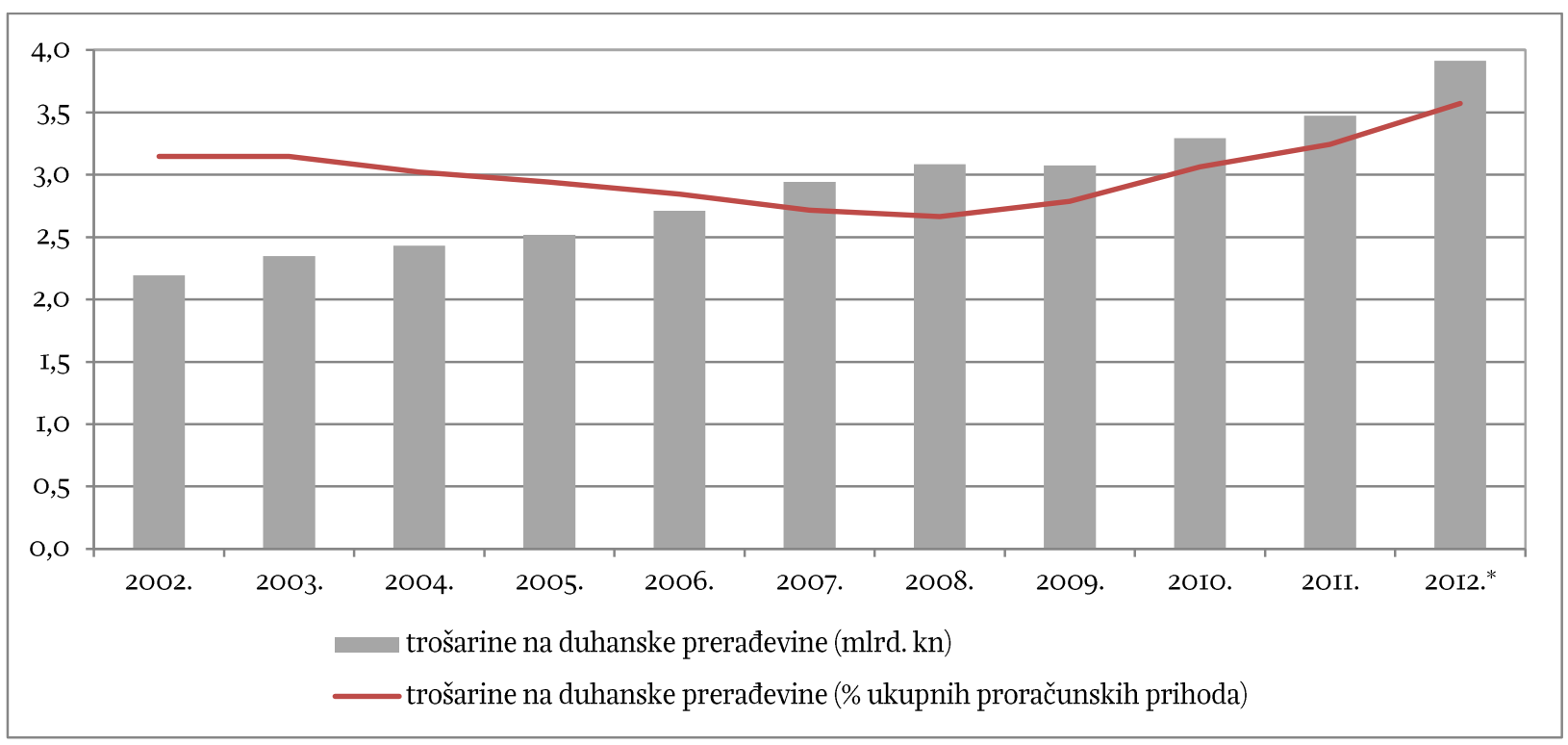

Napomena: *preliminarni podaci (za 20I2.).

Izvor: Ministarstvo financija $\mathrm{RH}, 2 \mathrm{OI} 3$.

\section{UTJEGAJ PROMJENA STRUKTURE TROŠARINE NA PRORAČUNSKE PRIHODE}

Promjene u strukturi trošarine na cigarete u Hrvatskoj utjecale su i na veličinu i dinamiku prikupljanja proračunskih prihoda. Početkom promatranog razdoblja prihodi od trošarine su stabilni uz relativno ujednačene mjesečne promjene tijekom godine (grafikon 2). Od 2009. se primjećuju veće promjene uzrokovane promjenom strukture trošarine (uvođenjem proporcionalne komponente). Naime, netom prije izmjena Zakona kojima se zadiralo u strukturu trošarine - prihodi od trošarine naglo rastu, a neposredno nakon donošenja Zakona naglo se smanjuju (grafikon 2).

Mogući razlog većih promjena je motiv proizvođača i/ili uvoznika da puste u prodaju što veću količinu cigareta po staroj (nižoj) trošarini, očekujući negativne učinke promjene Zakona. Oni tako postaju obveznici većeg iznosa trošarine, pa rastu i proračunski prihodi. Budući da se u tim trenucima u prodaju stavlja količina cigareta veća od uobičajene, u narednom se razdoblju u prodaju pušta razmjerno manja količina zbog čega su i prihodi od trošarine manji u vremenu neposredno nakon zakonskih promjena. 


\section{Grafikon 2.}

Mjesečna kretanja prihoda od trošarina na duhanske prerađevine od 200o. do 2013. (u tisućama kuna)

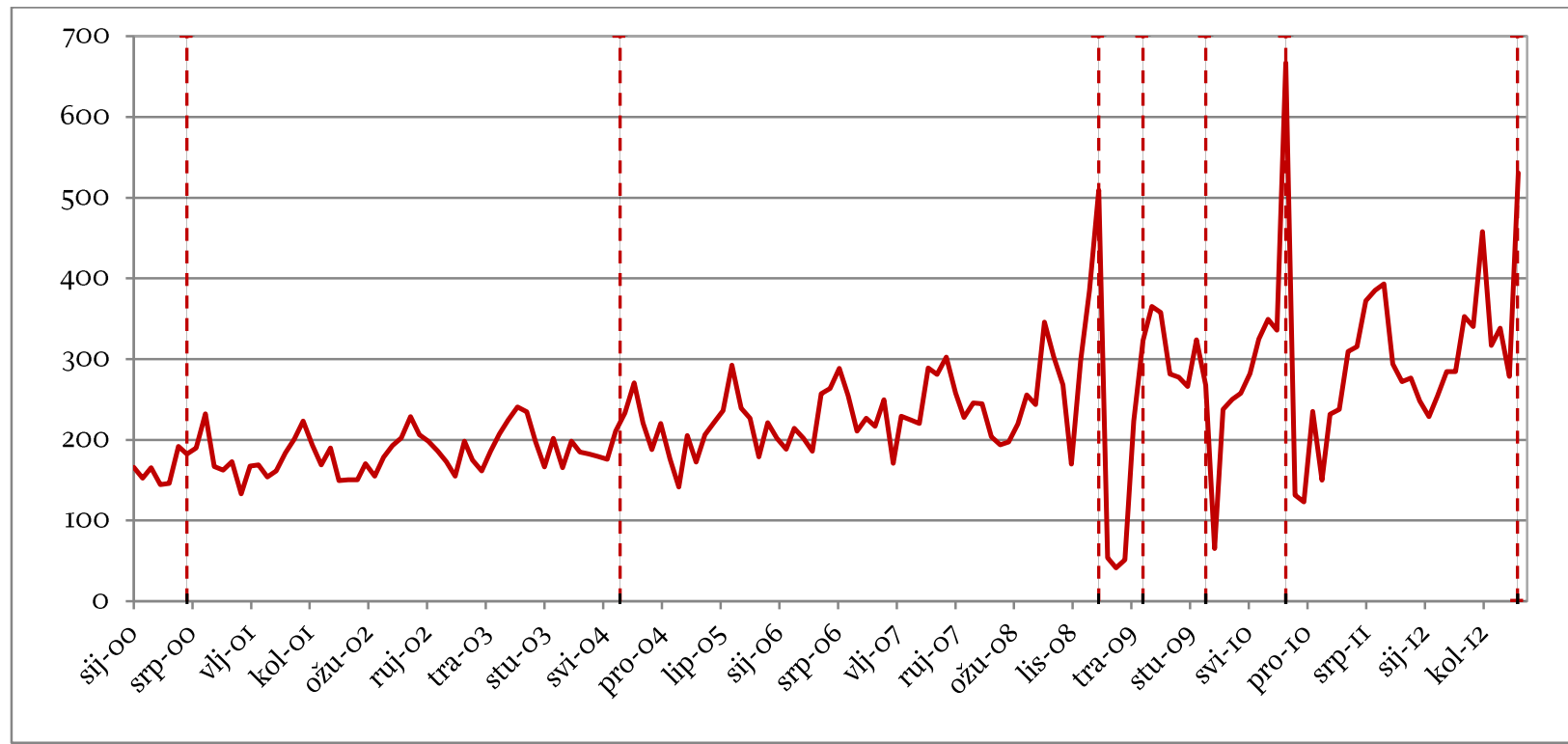

Napomena: Datumi izmjene zakonodavnog okvira označeni su okomitim isprekidanim linijama.

Izvor: Zakon o posebnom porezu na duhanske proizvode (NN I36/O2., 95/O4., I52/o8. i 38/og.), Zakon o trošarinama (NN 83/og. $i \mathrm{III} / \mathrm{I} 2$.) te Uredba o visini trošarine na cigarete $i$ sitno rezani duhan (NN I3I/I2.), Ministarstvo financija $R H, 2013$.

Analiza promjene strukture trošarine uz izračun prosječne vrijednosti specifične trošarine na cigarete $u$ razdoblju u kojem je bio na snazi višetarifni sustav, pokazuje da je u Hrvatskoj prisutan trend povećanja proporcionalne i smanjenja specifične komponente trošarine (grafikon 3).

\section{Grafikon 3.}

Struktura trošarine na cigarete u Hrvatskoj od I. 7. 2000. do prve polovice 20I3.

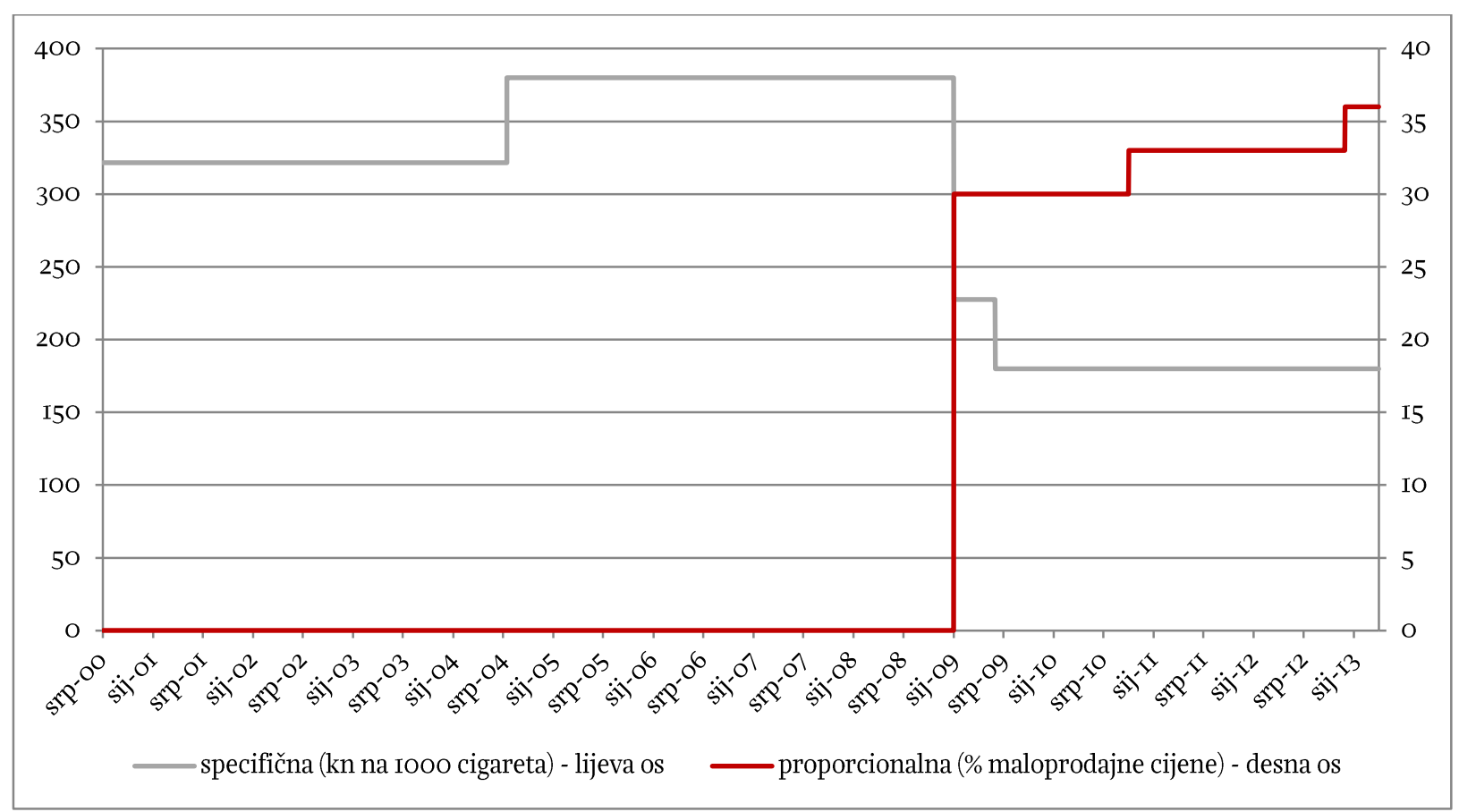

Izvor: Zakon o posebnom porezu na duhanske proizvode (NN i36/o2., 95/o4., I52/o8. i 38/og.), Zakon o trošarinama (NN 83/og. i III/I2.) i Uredba o visini trošarine na cigarete i sitno rezani duhan (NN I3I/I2.). 
Udio specifične trošarine u ukupnom poreznom opterećenju trebao bi do kraja 2017. biti između 7,5 i $76,5 \%$, a udio ukupne trošarine u prosječnoj ponderiranoj cijeni cigareta najmanje $60 \%$. Iako EU propisuje minimalne trošarine na cigarete, njihova je struktura (odnos specifične i proporcionalne komponente) $\mathrm{u}$ mjerodavnosti nacionalnih poreznih politika. Grafikon 4 prikazuje kretanje iznosa pojedinih dijelova trošarine na cigarete prema visini maloprodajne cijene cigareta u Hrvatskoj.

\section{Grafikon 4.}

Trošarina u odnosu na maloprodajnu cijenu cigareta u Hrvatskoj

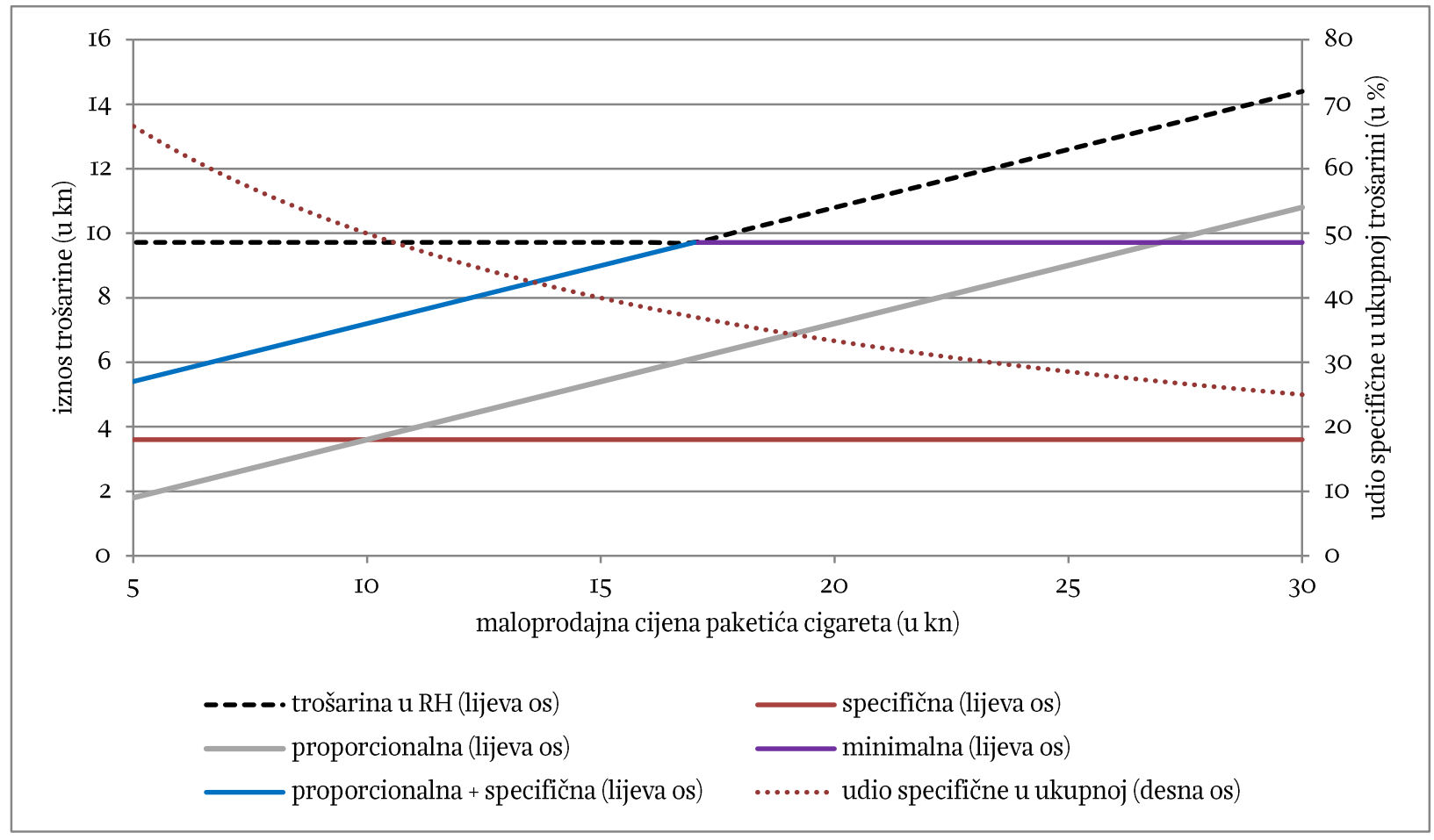

Izvor: Izračun autora.

Cigarete čija je maloprodajna cijena po paketiću (20 komada) do 17 kuna u Hrvatskoj se oporezuju minimalnom trošarinom od 486 kuna na I.ooo cigareta. ${ }^{4}$ Skuplje cigarete oporezuju se kombinacijom specifične i proporcionalne komponente trošarine.

Do maloprodajne cijene od to kuna iznos proporcionalne komponente je manji od iznosa specifičnog dijela trošarine. Na maloprodajnoj cijeni od to kuna udio proporcionalnog i specifičnog dijela u ukupnom iznosu trošarine se izjednačava, a daljnjim porastom maloprodajne cijene prevladava udio proporcionalne, a smanjuje se udio specifične komponente.

Povećanjem proporcionalne trošarine za 10\%, razlika u maloprodajnim cijenama cigareta kontinuirano raste povećanjem cijene cigareta prije poreza, dok povećanje specifične trošarine za Io\% uzrokuje (u apsolutnom iznosu) stalnu razliku u cijeni prije i nakon povećanja (grafikon 5).

\footnotetext{
4 Iznos ukupne trošarine (specifične i proporcionalne) na cigarete čija je maloprodajna cijena po paketiću do I7 kuna - obračunata prema važećim propisima - manji je od iznosa minimalne trošarine, pa se te cigarete oporezuju minimalnom trošarinom.
} 


\section{Grafikon 5.}

Simulacija povećanja pojedine komponente trošarine od Io\%

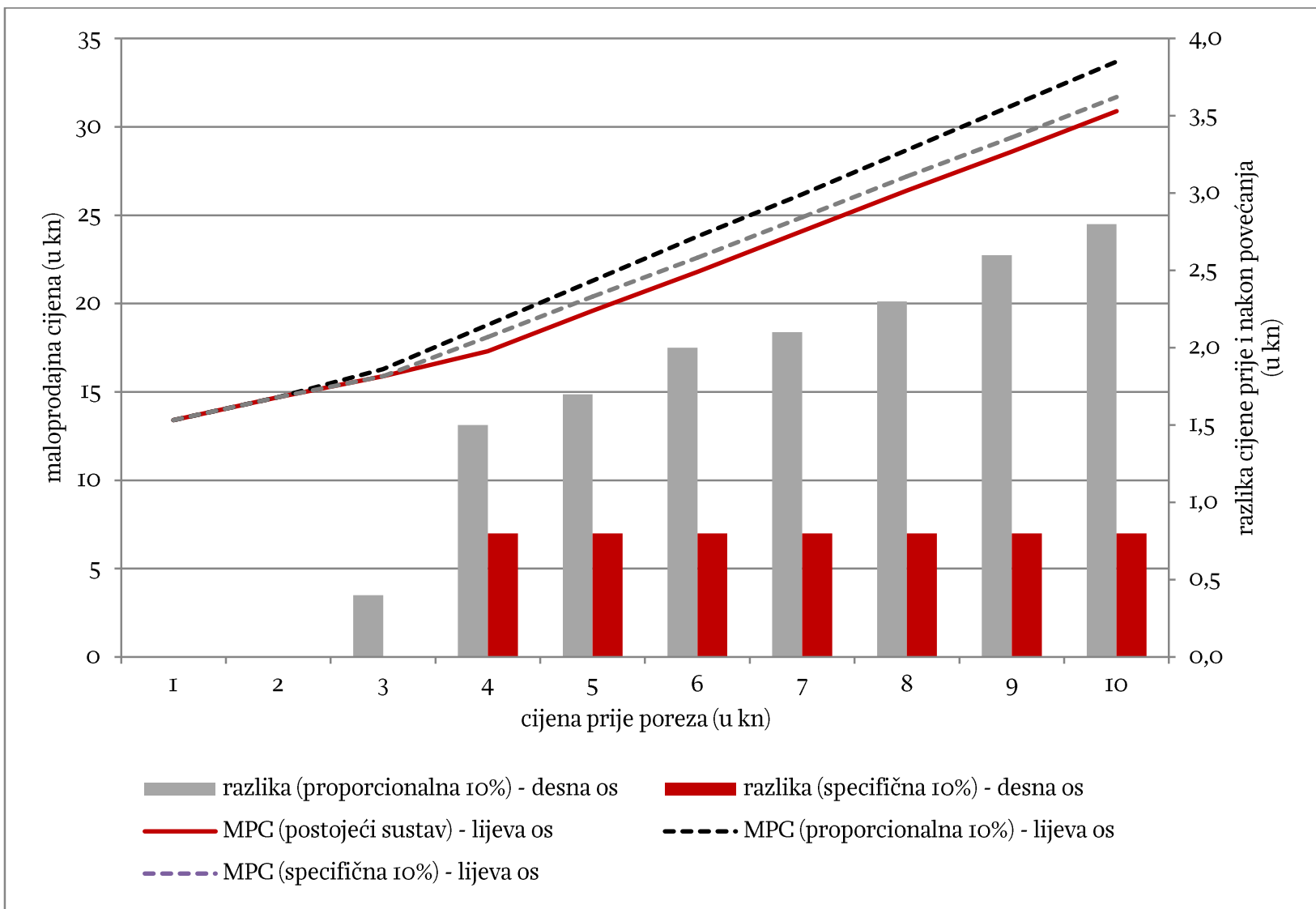

Napomena: Crte na grafikonu prikazuju kretanje maloprodajnih cijena cigareta u odnosu na cijenu prije poreza u važećem trošarinskom sustavu te simulacije maloprodajnih cijena uslijed povećanja specifičnog i proporcionalnog dijela trošarine od Io\%. Stupci označavaju razliku maloprodajnih cijena cigareta u postojećem sustavu i simulacije maloprodajnih cijena nakon Io\%-tnog povećanja pojedine komponente trošarine.

Izvor: Izračun autora.

\section{VISINA I STRUKTURA TOŠARINA NA GIGARETE U ZEMLJAMA EUROPSKE UNIJE}

Usporedba udjela prihoda od trošarina na cigarete $\mathrm{u}$ ukupnim proračunskim prihodima i BDP-u (grafikon 6) u Hrvatskoj i zemljama EU-a pokazuju da one predstavljaju značajan izvor proračunskih prihoda.

Trošarine na cigarete imaju relativno veći značaj (udio u ukupnim proračunskim prihodima) u novim zemljama članicama EU-a, dok su u starim članicama manje važan izvor prihoda. Apsolutna vrijednost prihoda od trošarina u starim zemljama članicama EU-a veća je nego u novim. Međutim, proračunski prihodi (kao i BDP) starih članica su toliko veliki da je relativan udio prihoda od trošarina na cigarete $u$ njima manje važan. 


\section{Grafikon 6.}

Udio prihoda od trošarina na cigarete u ukupnim proračunskim prihodima i BDP-u 2OII. (u \%)

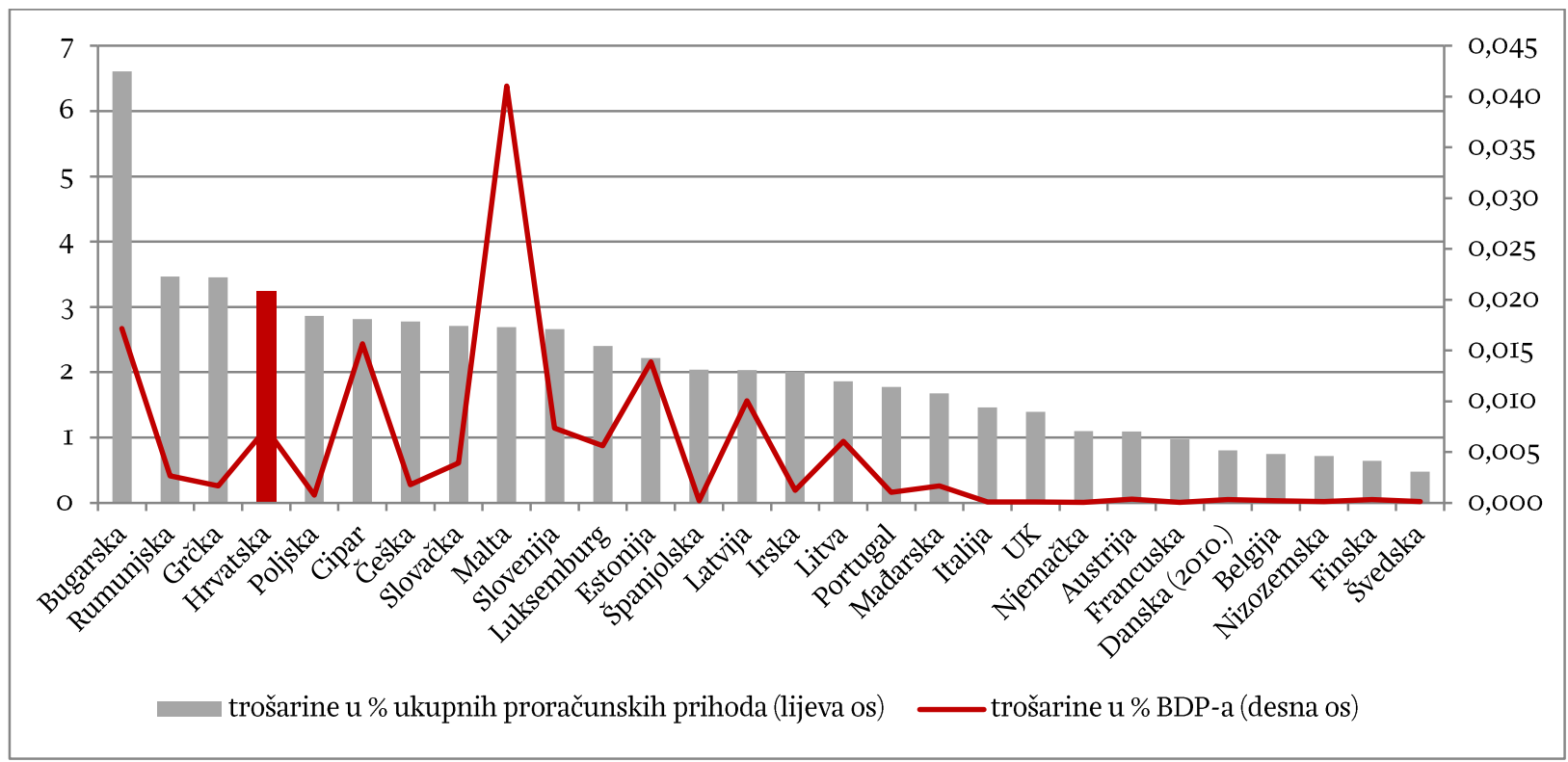

Napomena: Zbog nepostojanja javno dostupnih podataka o prihodima od trošarina na cigarete, podaci za Hrvatsku odnose se na ukupne prihode od trošarina na duhanske prerađevine.

Izvor: Eurostat i European Commission, 2012.

Udio trošarina na cigarete u maloprodajnoj cijeni u zemljama EU-a kreće se u rasponu od 56 do $72 \%$ (grafikon 7). Najmanji je u Švedskoj, Luksemburgu, Italiji i Belgiji, a najveći u UK-u, Nizozemskoj, Grčkoj i Estoniji. Opterećenje u Hrvatskoj manje je nego u EU-u, što dodatno potvrđuje činjenicu da će trošarina na cigarete u Hrvatskoj rasti. Međutim, pitanje je kako će se rast trošarine odraziti na njezinu strukturu.

\section{Grafikon 7.}

Visina trošarina na cigarete u zemljama Europske unije 2013. ( $\mathrm{u} \%$ maloprodajne cijene)

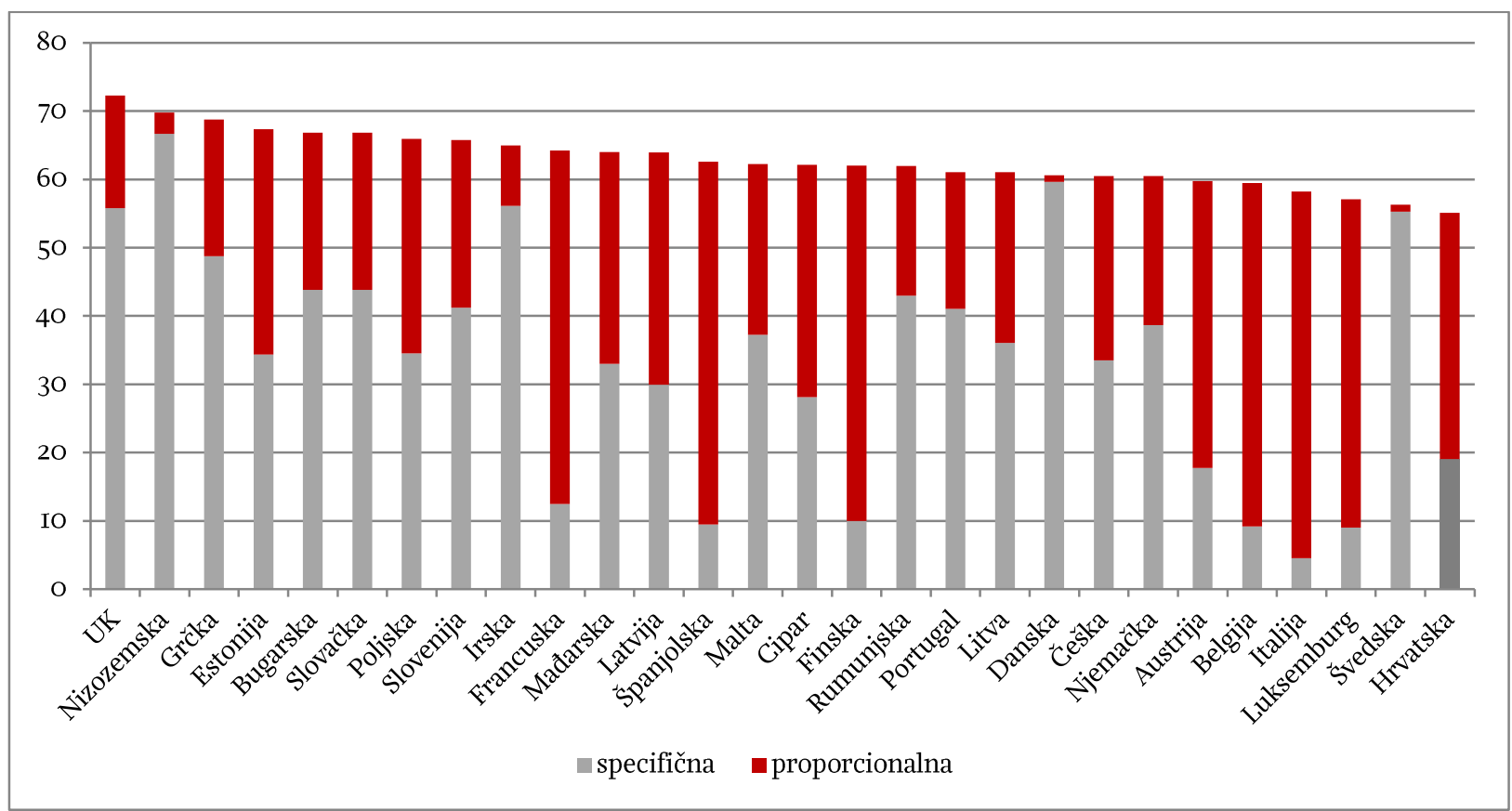

Izvor: European Commission, $2013 a$.

8 NEWSLETTER78 | ANTO BAJO I MARKO PRIMORAC | Struktura trošarine na cigarete u Hrvatskoj | Institut za javne financije 
Iako su propisani minimalni iznosi trošarina na cigarete, države članice EU-a nemaju jedinstven stav o poželjnoj strukturi (v. grafikone 7 i 8) pa se udio specifične u ukupnoj trošarini kreće u prilično širokom rasponu od $8 \%$ do $98 \%$ (udio proporcionalne od 2\% do 92\%). Specifičnu trošarinu izrazito preferiraju Danska, Švedska i Nizozemska, a proporcionalnu Italija, Španjolska, Belgija, Luksemburg, Finska i Francuska. U Hrvatskoj trenutno dominira proporcionalna komponenta sa $65 \%$ udjela u ukupnoj trošarini. Samo sedam zemalja EU-a ima u strukturi trošarina na cigarete izraženiji udio proporcionalne komponente od Hrvatske.

\section{Grafikon 8.}

Struktura trošarina na cigarete zemalja Europske unije u 2013.

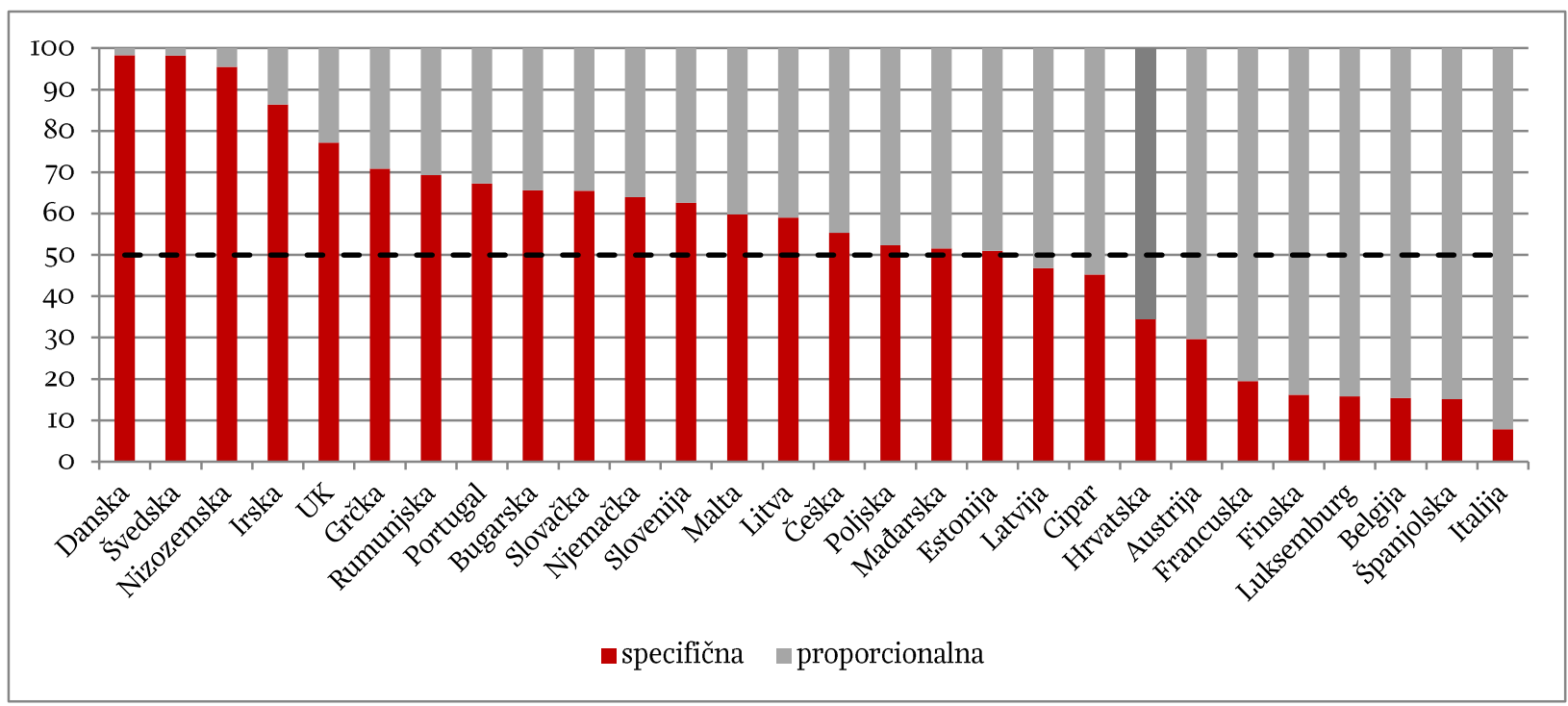

Izvor: European Commission, $2013 a$.

Razlike $u$ strukturi trošarina rezultiraju različitim maloprodajnim cijenama cigareta, ali i različitim prihodima. Načelno je niža cijena cigareta povezana s manjim prihodima od trošarina. Međutim, analizom pojedinačnih slučajeva može se uočiti odstupanje od tog trenda zbog strukture trošarina i potrošnje (grafikon P-I). Slična je situacija i s količinom cigareta puštenih u potrošnju. Veća količina cigareta trebala bi utjecati na veće prihode od trošarina, što često nije slučaj (grafikon P-2).

U skladu sa smjernicama EU-a, zemlje članice su na nacionalnoj razini uvele i minimalne trošarine koje se u 2013. kreću od 67,19 do 271,91 eura na 1.00o cigareta (grafikon P-3). Stare zemlje članice EU-a uglavnom imaju više minimalne trošarine od novih.

\section{ZAKLJUČAK}

Zemlje EU-a nemaju jedinstven stav o strukturi trošarina na cigarete, pa im udio specifične i proporcionalne $\mathrm{u}$ ukupnoj trošarini značajno varira. Udio pojedine komponente $\mathrm{u}$ ukupnoj trošarini utječe na maloprodajnu cijenu cigareta, na strukturu potrošnje i na prihode od trošarina.

Visina trošarine na cigarete $\mathrm{u}$ Hrvatskoj mijenjala se od 200o. nekoliko puta zbog usklađivanja s EU-om, što je uglavnom utjecalo na rast cijena cigareta i prihoda proračuna. Udio trošarine na cigarete $u$ maloprodajnoj cijeni u Hrvatskoj znatno je niži nego u zemljama EU-a. Zbog daljnje harmonizacije s EU-om trošarina na cigarete će u Hrvatskoj i dalje rasti, zbog čega će cijena cigareta dodatno porasti.

Prihodi od trošarine na cigarete u Hrvatskoj rastu i značajan su prihod državnog proračuna, ali još uvijek manje značajan nego u većini zemalja članica EU-a. Zbog promjena strukture trošarine, od 20og. su 
primjetne znatne oscilacije $\mathrm{u}$ mjesečnom kretanju prihoda od trošarine. Čini se da su u pojedinim razdobljima proizvođači i uvoznici (neposredno prije promjene visine i strukture trošarine) stavljali veću količinu cigareta u promet po staroj (nižoj) trošarini.

U hrvatskoj ne postoji detaljnija analiza i procjena vrijednosti prometa i izgubljenih proračunskih prihoda uslijed ilegalne trgovine te legalnih kupovina u pograničnim područjima s državama koje imaju niže cijene cigareta. Vlada i Ministarstvo financija daljnje promjene visine i strukture trošarine trebaju temeljiti na kvalitetnim procjenama njihova utjecaja na strukturu proizvodnje i potrošnje, cijene proizvoda i prihode državnog proračuna. Mogućnosti detaljnije analize fiskalnih i ostalih ekonomskih učinaka trošarine ograničene su zbog nedostatka javno dostupnih podataka. Javna objava podataka o količinama cigareta puštenih u potrošnju po različitim cjenovnim kategorijama umnogome bi olakšala daljnja istraživanja. Isto tako, podaci o strukturi trošarina na duhanske prerađevine, iz kojih bi se mogli zasebno izdvojiti prihodi od trošarine na cigarete, omogućili bi vjerodostojniju usporedbu s ostalim zemljama.

\section{PRILOG I.}

\section{Grafikon P-I.}

Cijena i prihodi od trošarina na cigarete u 2013. (u eurima na 1.ooo cigareta)

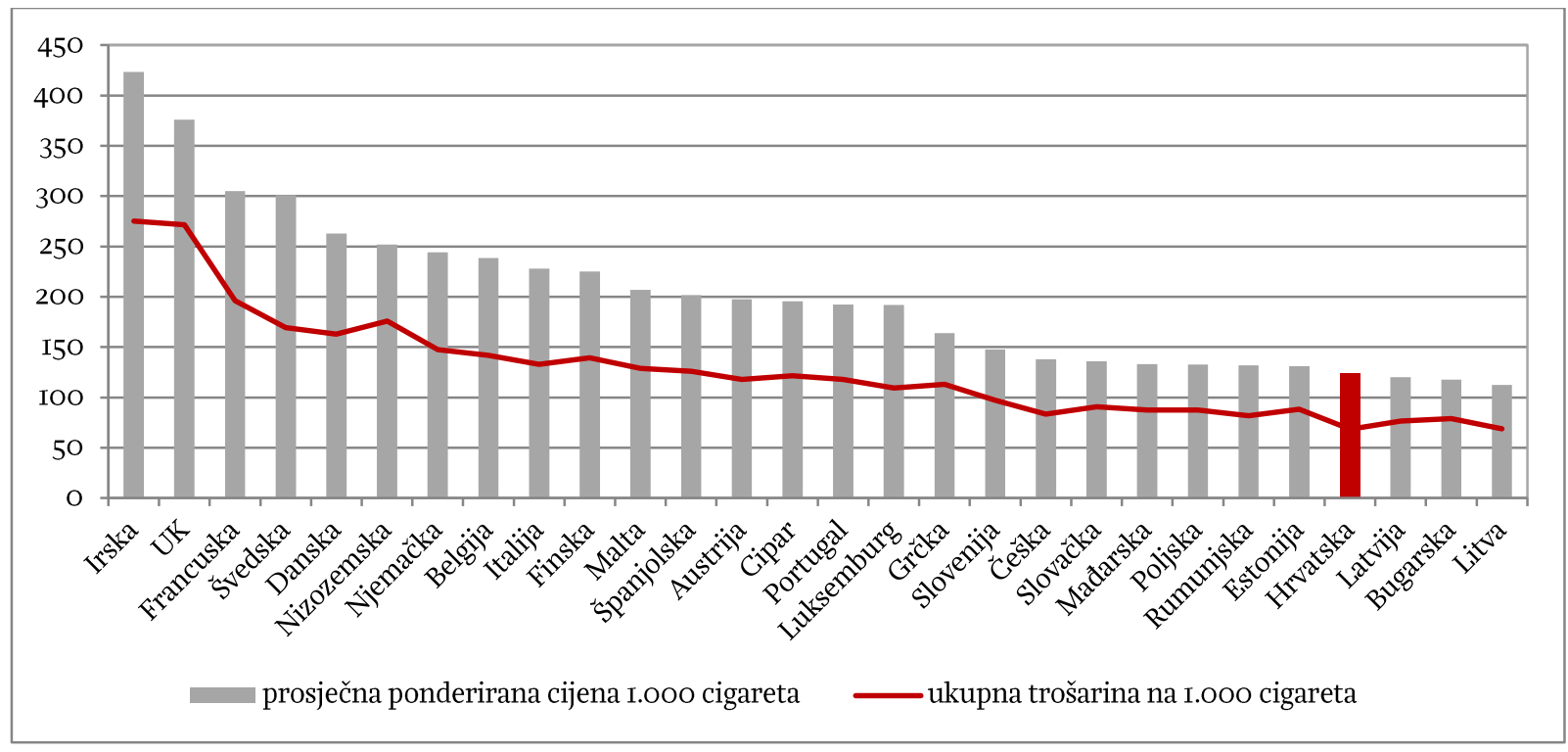

Izvor: European Commission, $2013 a$. 


\section{Grafikon P-2.}

Odnos ukupnog broja cigareta puštenog u potrošnju i ukupnog prihoda od trošarina na cigarete u 2011.

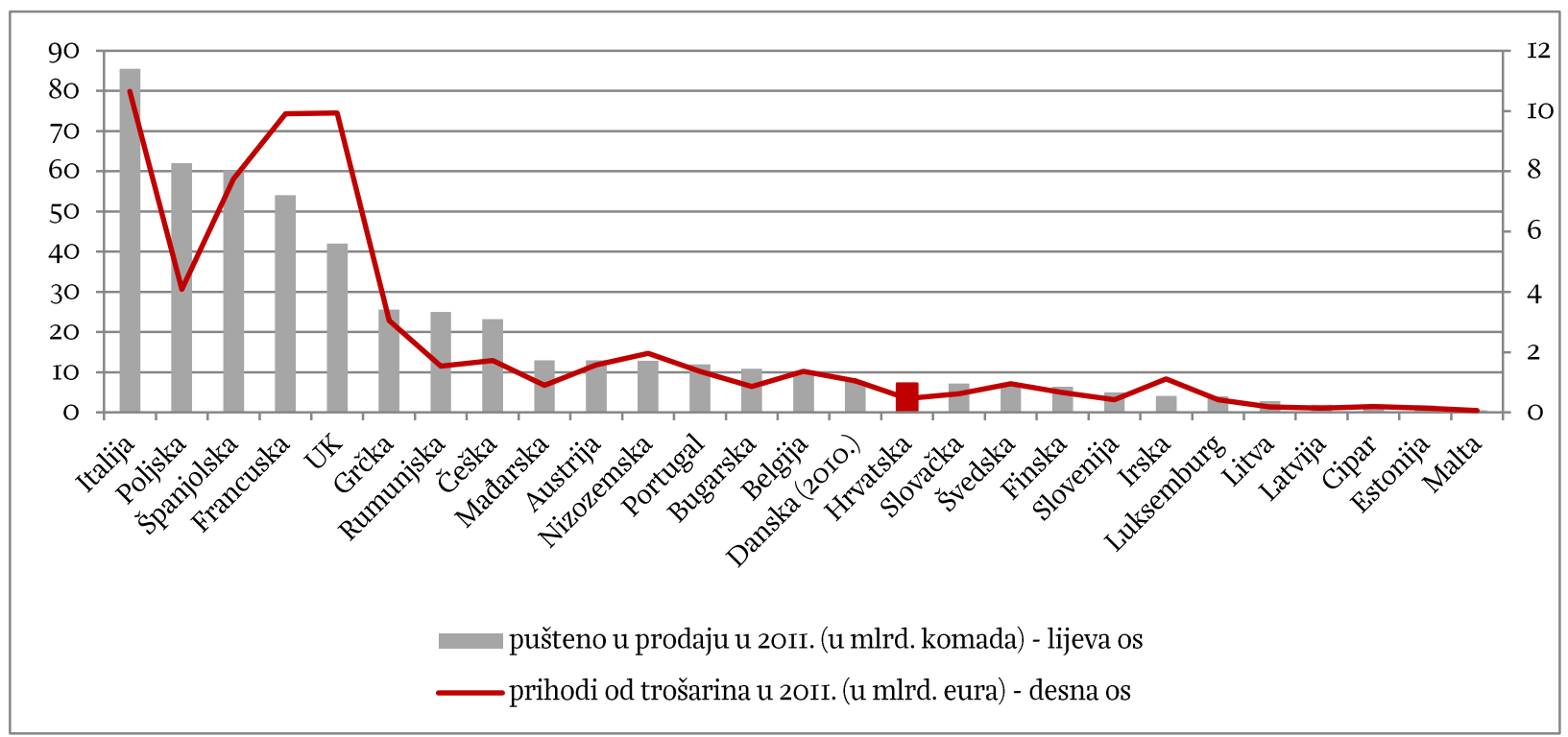

Izvor: European Commission (2012; 2013b).

\section{Grafikon P-3.}

Minimalne trošarine u zemljama Europske unije u 2013. (\% maloprodajne cijene i euro na r.ooo cigareta)

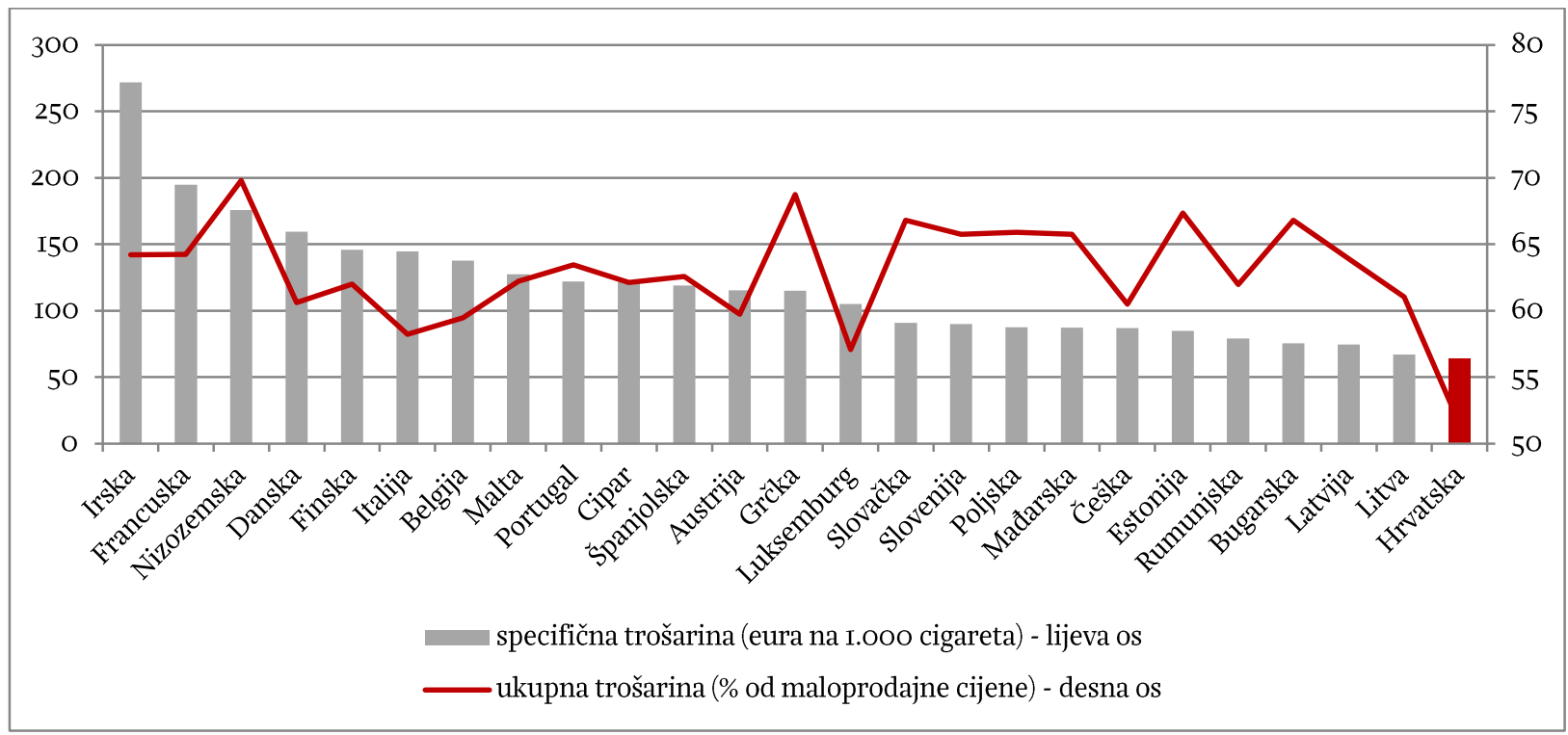

Napomena: Podaci za Njemačku, Švedsku i UK nisu dostupni.

Izvor: European Commission, 20I3a. 


\section{LITERATURA}

Cnossen, S., 1992. „Intrigues around the tobacco excise in the European Community”. International Tax Review, 2, 127-I37.

Gnossen S., 2001. „How Should Tobacco Be Taxed In EU-Accession Countries?” CESifo Working Paper No. 539 .

Delipalla, S. and O'Donnell, O., 1998. The Comparison between Ad Valorem and Specific Taxation under Imperfect Competition: Evidence from the European Cigarette Industry.

European Commission, 2012. Excise Duty Tables: Tax receipts - Manufactured Tobacco. Bruxelles: European Commission.

European Commission, 2013a. Excise Duty Tables: Part III - Manufactured Tobacco. Bruxelles: European Commission.

European Commission, 2013b. Releases for consumption of cigarettes 2002-20II. Bruxelles: European Commission.

Keen, M., 1998. „The Balance between Specific and Ad Valorem Taxation”. Fiscal Studies, I9(I), str. I-37.

Marinović, ž, 20I3. „Novine kod trošarina na cigarete i sitno rezani duhan”. Carinski vjesnik, 22(I), str. 29-5I.

Ministarstvo financija RH, 2013. Vremenske serije podataka. Zagreb: Ministarstvo financija.

Matrix insight, 2012. Economic analysis of the EU market of tobacco, nicotine and related products. Matrix insight Ltd.

Ross, H., 2004. „The Economics of Tobacco and Tobacco Control in the European Union, u Tobacco or Health in the European Union: past, present and future". European Commission, Directorate-General for Health and Consumer Protection, str. 69-98.

Uredba o visini trošarine na cigarete i sitno rezani duhan, NN 13I/12. Zagreb: Narodne novine.

Zakon o posebnom porezu na duhanske proizvode, NN 136/O2., 95/O4., 152/o8. i 38/o9. Zagreb: Narodne novine.

Zakon o trošarinama, NN 83/og., III/I2. i 22/I3. Zagreb: Narodne novine. 